\title{
Kajian Hukum Terhadap Penerapan Eksekusi Hukuman Kebiri Bagi Pelaku Kekerasan Seksual Terhadap Anak
}

\author{
Defi Muslimah $^{1}$, Siswanto $^{2}$ \\ Universitas Pancasakti Tegal \\ Jalan Halmahera KM 1 Mintaragen Tegal \\ devimuslimah278@gmail.com, siswanto@upstegal.ac.id \\ Masuk: 2 Mei 2020; Diterima: 27 Mei 2020; Terbit: 29 Mei 2020. \\ DOI: $10.24905 /$ diktum.v8i1.86
}

\begin{abstract}
The Second Amendment to Law No. 23 on child protection into law No. 17 of 2016 is a new governmentconducted trobored as an attempt to minimize sexual violence against children. The boredom is contained in article 7, which enforces additional penalties in the form of chemical decadation and the installation of electronic equipment for sexual violence. The provisions of article 7 related to the punishment of the sheep finally apply and are applied for the first time by the ruling of a Mojokerto court judge. The problem formulation in this research is about legislation number 16 of 2017 about as the Second Amendment to Law No. 23 of 2002 on child protection in conflict with human rights health and How the implementation of execution of the determination of the sentence of the sheep without instructions on the implementation. The study used a focus judicial case study. The type of research used is literature research. The approach is to use a normative approach. The data types used are secondary data. Sources of research data are obtained from secondary legal materials. Data processing methods use library search. Method of data analysis is done by qualitative method. The results showed that the enactment of the sentence of the law did not necessarily reduce the sexual violence of children. Punishment is essentially a violation of human rights, but must be done humanely. The act of sexual violence against children is an act of desire to satisfy sexual desire, even though the punishment of the sheep can not break the desire to do so. The granting of a sheep sentence against the perpetrator will not give a deterrent effect to the perpetrator, the death penalty is a proper punishment for obtaining it. Legal certainty becomes one of the objectives of the law, on the basis of the legality of all things must be done and implemented based on the existing provisions, the absence of technical instructions in the implementation of the Capon to make the principle of legality Applies only to the sound of the article stating a type of crime, offence and sentence without any instruction in the execution of the sentence.
\end{abstract}

Keywords : Kebiri, Sexual, child 


\begin{abstract}
Abstrak
Perubahan kedua Undang-undang Nomor 23 tentang Perlindungan Anak menjadi Undang-undang Nomor 17 tahun 2016 merupakan trobosan baru yang dilakukan pemerintah sebagai upaya untuk meminimalisir terjadinya kekerasan seksual terhadap anak. Trobosan tersebut tertuang dalam pasal 7 yang memberlakukan hukuman tambahan berupa hukuman kebiri kimia dan pemasangan alat penditeksi elektronik bagi pelaku kekerasan seksual. Ketentuan pasal 7 terkait dengan hukuman kebiri akhirnya berlaku dan diterapkan untuk pertama kalinya oleh putusan hakim Pengadilan Mojokerto. Rumusan masalah pada penelitian ini adalah mengenai kerelevansi undang-undang Nomor 16 tahun 2017 tentang sebagai perubahan kedua atas Undang-undang Nomor 23 tahun 2002 tentang perlindungan anak yang berbenturan dengan Hak Asasi Manusia Kesehatan dan bagaimana kerelevansi pelaksanaan eksekusi terhadap hukuman kebiri tanpa adanya petunjuk pelaksanaannya. Penelitian ini menggunakan focus judicial case study. Jenis Penelitian yang digunakan adalah penelitian kepustakaan. Pendekatan dilakukan adalah dengan menggunakan pendekatan normative. Jenis data yang digunakan meruapakan data sekunder. Sumber data penelitian diperoleh dari bahan hukum sekunder. Metode pengolahan data menggunakan Penelusuran kepustakaan. Metode analisis data dilakukan dengan metode kualitatif. Hasil penelitian menunjukan, bahwa diberlakukannya hukuman kebiri tidak serta merta dapat meminimalisir adanya kekerasan seksual terhadap anak. Hukuman pada dasarnya melanggar hak asasi manusia, tetapi harus tetap dilakukan dengan manusiawi. Perbuatan kejahatan kekerasan seksual terhadap anak merupakan perbuatan yang mucul dari adanya keinginan untuk memuaskan hasrat seksual, meskipun dengan diberlakukan hukuman kebiri tidak bisa memutus keinginan untuk melakukan hal tersebut. Pemberian hukuman kebiri terhadap pelaku tidak akan memberikan efek jera bagi pelaku, hukuman mati merupakan hukuman yang pantas untuk didapatkannya. Kepastian hukum menjadi salah satu tujuan dari hukum, berdasarkan asas legalitas segala sesuatu tentu harus dilakukan dan dilaksanakan berdasarkan ketentuan yang ada, belum adanya petunjuk pelaksanaan dan teknis dalam hukuman kebiri menjadikan asas legalitas hanya berlaku bagi sebuah bunyi pasal yang menyatakan suatu jenis kejahatan, pelanggaran dan hukumannya tanpa adanya petunjuk pelaksanaan dalam menerapakan hukuman.
\end{abstract}

Kata Kunci : Kebiri, Seksual , Anak

\title{
A. Pendahuluan
}

Anak merupakan generasi muda yang menjadi asset suatu negara, yang dapat meneruskan cita-cita perjuangan bangsa. Seorang anak dalam tahap tumbuh kembangnya haruslah selalu didampingi, diawasi dan dilindungi oleh orang tua. Kewajiban untuk melindungi anak bukan hanya dilakukan oleh orang tua saja, melainkan menjadi kewajiban pula bagi setiap keluarga, masyarakat, pemerintah dan terutama oleh Negara. Negara mempunyai peranan yang sangat penting untuk melakukan perlindungan terhadap anak agar anak dapat tumbuh dan berkembang dengan baik dan menjadi generasi yang berkualitas dan menjadi harapan bagi Negara untuk memegang tongkat estafet pemerintahan menggantikan pemimpin-pemimpin saat ini.

Pembukaan Undang-Undang Negara Republik Indonesia tahun 1945 alenia ke 4 terdapat tujuan Negara yang salah satunya adalah melindungi segenap bangsa Indonesia dan seluruh tumpah darah Indonesia. Tujuan negara itulah yang menjadi dasar pemerintah Indonesia mempunyai kewajiban 
melindungi rakyatnya, dan terutama melindungi anak-anak generasi penerus bangsa. Pemerintah dalam melakukan perlindungan anak telah melakukan bergai upaya-upaya penegakan hukum terhadap perlindungan anak, dan membuat trobosan-trobosan baru untuk memberi efek jera kepada setiap orang yang melakukan tindakan kekerasan terhadap anak.Melalui berbagai macam undangundang yang dibuat oleh pemerintah, yang pada khususnya dibuat dan disusun oleh lembaga legislatif bersama dengan lembaga eksekutif, undang- undang tersebut berlaku dan bersifat mengikat pada setiap orang. ${ }^{1}$

Pembentukan peraturan perundang-undangan dengan hukuman pidana penjara yang begitu berat tidak sepenuhnya memberikan rasa takut dan jera bagi pelaku kekerasan terhadap anak. Kasus-kasus kekerasan seksual terhadap anak semakin meningkat, kasus demi kasus mulai muncul kepermukaan public dan menarik perhatian masyarakt luas. Kekerasan seksual di Jakarta Internasional School menjadi awal kegeraman masyarakat yang menimbulkan 3 korban anak yang dilakukan oleh 7 orang yang terdiri dari 5 orang petugas kebersihan dan 2 orang guru, yang kemudian pada tahun yang sama yaitu 2014 muncul kembali kasus pelecehan seksual oleh Arif Sobari (AS) alias emon di Sukabumi yang memakan korban anak yang begitu banyak, hingga mencapai 55 anak, dan masih banyak lagi kasus-kasus kekerasan seksual lainnya. Kegeraman masyarakat dan pemerintah atas pelaku kekerasan seksual kemudian direspon dengan tanggap oleh pemerintah.

Pemerintah merespon dengan melakukan trobosan baru untuk memberi efek jera kepada pelaku kekerasan seksual terhadap anak dengan mengundangkan peraturan pemerintah Pengganti Undang-undang Nomor 1 tahun 2016 tentang perubahan kedua atas Undang-undang Nomor 23 tahun 2002 tentang Perlindungan anak. Peraturan yang dikeluarkan mengatur tentang pidana tambahan bagi pelaku yang melanggar ketentuan pasal $76 \mathrm{D}$ yang berbunyi " setiap orang dilarang melakukan kekerasan atau ancaman kekerasan memaksa anak melakukan persetubuhan dengannya atau dengan orang lain" dengan ancaman pidana tambahan berupa hukuman kebiri bagi pelaku kekerasan seksual dan residivis kekersan seksusal terhadap anak. Ketentuan pidana kebiri diatur dalam Pasal 7 yang menyebutkan bahwa terhadap Pelaku

\footnotetext{
${ }^{1}$ Sudewo Fajar Ari, dkk, The Application Of Restorative Justice System Through The Diversion Of Children In Conflict With Laws In Central Java Polda (Regional Police Of The Republic Of Indonesia), International Journal of Psychosocial Rehabilitation Volume 24 (2), 2020. hlm 3802-3810.
} 
sebagaimana dimaksud pada ayat (4) (residivis) dan ayat (5) (Pelaku tindakan kekerasan seksusal terhadap anak yang memakan korban lebih dari 1 orang) dapat dikenai tindakan pidana tambahan berupa kebiri kimia dan pemasangan alat penditeksi elektronik.

Harapan besar bagi Negara dengan adanya hukuman pidana tambahan ini untuk meminimalisir atau mencegah terjadinya tindak kekerasan seksual terhadap anak, namun kenyataannya kasus kekerasan seksual terhadap anak masih kerap terjadi saat ini. Muncul suatu kasus yang sempat kembali menyita perhatian public, yaitu kasus pemerkosaan 9 anak dibawah umur yang masih berada dibangku Taman Kanak-kanak yang dilakukan oleh Muh Aris di Mojokerto Jawa Timur. Dengan dijatuhkan vonis bersalah pada Muhammad Aris karena melanggar pasal 76 D Juncto Pasal 81 ayat (2) UU RI Nomor 23 tahun 2002 tentang perlindungan anak, yang tertuang dalam putusan Pengadilan Negeri Mojokerto Nomor 69/Pid.sus/PN.Mjk tanggal 2 Mei 2019 dengan hukuman penjara 12 tahun dan denda 100 juta subsider 6 bulan kurungan serta tambahan hukuman tambahan berupa hukuman kebiri. ${ }^{2}$

Harapan dengan tujuan untuk meminimalisir atau mencegah terjadinya tindak kekerasan seksual terhadap anak oleh Negara dengan menambahkan hukuman yang begitu berat, kini menuai beberapa kontroversi. Beberapa kalangan masyarakat menilai bahwa hukuman kebiri merupakan langkah yang sudah sangat tepat terhadap kejahatan yang telah dilakukan, namun sebagaian dari kalangan akademisi menganggap hukuman kebiri merupakan hukuman yang tidak manusiawi dan melanggar Hak Asasi Manusia. Putusan hukuman kebiri pertama kali di Indonesia ini telah menuai berbagai macam problematika dalam pelaksanaannya, baik bertentangan dari sisi hak asasi manusia, Undangundang kesehatan dan etika profesi dokter, hingga petunjuk pelaksanaan hukuman kebiri yang belum ada sebagai pedoman pelaksanaan hukuman kebiri.

\section{B. Rumusan Masalah}

1. Bagaimana relevansi kajian hokum terhadap pidana kebiri menurut Perlindungan anak yang bertentangan dengan Hak Asasi Manusia dan Kode Etik Kedokteran?

2. Bagaimana pemberlakuan eksekusi terhadap hukuman kebiri?

\footnotetext{
2 liputan6, " PN Mojokerto: Hukuman Kebiri Kimia Terhadap Pemerkosa Anak Berpatok Undangundang", diakses dari https;//m.liputan6.com/Surabaya/read/4047883/pn/mojokerto-hukumankebiri-kimia-terhadap-pemerkosa-anak-berpatok-uu, Kamis ,Tanggal 29, Agustus tahun 2019
} 


\section{Metode Penelitian}

1. Fokus Penelitian

Penelitian yang dilakukan merupakan penelitian yang berfokus pada penelitian terhadap judicial case study. Penelitian judicial case study adalah penelitian terhadap sengketa hukum dalam hal ini yang telah diselesaikan melalui putusan Pengadilan Negeri. Dalam hal ini, penelitian ini berkaitan dengan pelaksanaan eksekusi hukuman kebiri terhadap putusan hakim³.

2. Jenis Penelitian

Jenis penelitian ini adalah penelitian kepustakaan (Library Research). Penelitian kepustakan menurut Soerjono Soekanto (2007:13) adalah penelitian hukum yang dilakukan dengan cara meneliti bahan pustaka atau data sekunder belaka yang diperoleh dari berbagai sumber seperti jurnal, skripsi, buku, artikel-artikel dan bahan kepustakaan lainnya ${ }^{4}$. Peneliti dalam melakukan penelitian menggunakan data yang diperoleh dari suatu Undangundang yaitu Undang-undang Nomor 17 tahun 2016 Tentang Penetapan Peraturan Pemerintah Pengganti Undang-Undang Nomor 1 Tahun 2016 beserta Undang-Undang Nomor 39 Tahun 1999 Tentang Hak Asasi Manusia. Beberapa referensi buku yang terkait dengan judul penelitian.

3. Pendekatan Penelitian

Penelitian ini dilakukan dengan menggunakan pendekatan normative. Pendekatan normative adalah pendekatan yang dilakukan dengan berdasarkan pada norma-norma hukum atau kaidah-kaidah hukum. Pendekatan ini dilakukan dengan menelaah dan mengkaji peraturan perundang-undangan yang terkait dengan penelitian ini.

4. Jenis Data

Data yang digunakan dalam penelitian ini adalah berupa data sekunder. Data sekunder adalah bahan-bahan hukum yang berupa semua publikasi tentang hukum yang meliputi buku-buku teks, kamus-kamus hukum, jurnal-jurnal hukum, komentar-komentar atas putusan pengadilan ${ }^{5}$.

5. Sumber Data

Sumber data yang digunakan untuk menjawab persoalan dalam penelitian ini adalah data-data yang diperoleh dari bahan hukum sekunder. Bahan hukum sekunder yang digunakan dalam penelitian ini yaitu dengan menggunakan

\footnotetext{
${ }^{3}$ Peter Mahmud Marzuki, penelitian hukum, Jakarta: Kencana,2007, hal.94

${ }^{4}$ Nurul Qamar, dkk, "Metode Penelitian Hukum (Legal Research Methods)"

5 Peter Mahmud Marzuki, penelitian hukum, Jakarta: Kencana,2016, hal.102
} 
beberapa peraturan perundang-undangan seperti Undang-undang yaitu Undang-undang Nomor 17 tahun 2016 Tentang Penetapan Peraturan Pemerintah Pengganti Undang-Undang Nomor 1 Tahun 2016 beserta Undang-Undang Nomor 39 Tahun 1999 Tentang Hak Asasi Manusia dan buku-buku yang berkait dengan penelitian ini.

6. Metode Pengolahan Data

Metode penelitian data yang digunakan dalam penelitian ini adalah dengan cara penelusuran kepustakaan. Penelusuran kepustakaan adalah teknik pengumpulan data melalui penelaahan dokumen-dokumen. Penelusuran kepustakaan dilakukan secara online dan offline. Penelusuran secara online dengan cara searching buku-buku online yang terkait dengan penelitian di Internet. Penelusuran secara offline dengan cara peneliti mengunjungi perpustakaan, dan meminjam buku referensi yang terkait dengan penelitian ini.

7. Metode Analisis Data

Analisis data yang dilakukan dalam penelitian ini adalah analisis kulitatif. Analisis Kualitatif adalah upaya yang dilakukan dengan jalan bekerja dengan data, mengorganisasikan data, memilah-milahnya menjadi satuan yang dapat dikelola, mensintesiskannya, mencari dan menemukan pola, menemukan apa yang penting dan apa yang dipelajari dan memutuskan apa yang dapat uraikan ${ }^{6}$. Analisis penelitian ini dilakukan dengan mengumpulkan berbabagi sumber hukum dari beberapa bahan-bahan hukum sekunder yang digunakan yang kemudian dicari hal-hal yang dapat menjadi jawaban dari permasalahan yang akan dicari jawabannya, dan selanjutnya diuraikan dalam bentuk deskripsi sebagai jawaban dari permasalahan dalam penelitian ini.

\section{Pembahasan}

1. Kerelevansian Undang-undang Nomor 17 tahun 2016 tentang Penetapan Peraturan Pemerintah Pengganti Undang-undang Nomor 1 tahun 2016 tentang perubahan kedua atas Undang-undang Nomor 23 tahun 2002 tentang Perlindungan anak yang berbenturan dengan Hak Asasi Manusia

Hukuman kebiri berlaku di Indonesia sejak dikeluarkannya peraturan pemerintah pengganti undang-undang, yang kemudian ditetapkan dalam Undang-undang Nomor 17 tahun 2016 tentang perubahan kedua atas

6 Faricha Ni'mah, 2015 , Analisis Data dalam Penelitian Kualitatif, diakses dari https://www.google.com/amp/s/www.kompasiana.com/amp/farichatun/analisis-data-dalampenelitian-kualitatif_556b6d1f2ab0bd174de40eed, Selasa, 24 Desember, 2019, 22:24 
Undang-undang Nomor 23 tahun 2002 tentang Perlindungan anak. Hukuman ini merupakan hukuman tambahan yang dapat dikenakan kepada pelaku kekerasan seksual terhadap anak. Ketentuan dalam penjatuhan hukuman kebiri kimia diatur dalam pasal 81 ayat (4), (5), dan (7), yaitu apabila perbuatan yang dilakukan menimbulkan korban lebih dari 1 (satu) orang, mengakibatkan luka berat, gangguan jiwa, penyakit menular, terganggu atau hilangnya fungsi reproduksi, dan/atau korban meninggal dunia serta berlaku juga bagi pelaku kekerasan seksual yang termasuk residivis. Kekerasaan seksual terhadap anak yang semakin meningkat dan adanya seks menyimpang yang dilakukan oleh para pelaku kekerasaan seksual yang kemudian membuat pemerintah memberlakukan hukuman kebiri sebagai trobosan dalam meminimalisir tingkat kejahatan kekerasan seksual terhadap anak yang semakin meningkat. ${ }^{7}$

Berlakunya hukuman kebiri ini kemudian menjadi perbincangkan public saat adanya penerapan hukuman kebiri pertama kali yang diterapkan dalam putusan pengadilan Mojokerto. Pengadilan Mojokerto menjatuhkan hukuman tambahan berupa hukuman kebiri kimia kepada pelaku kekerasan seksual yang dilakukan oleh Muh Aris. Putusan pengadilan tersebut kemudian menuai pro dan kontra dari beberapa kalangan, baik dari kalangan akademisi maupun dari kalangan masyarakat . Pro dan kontra inilah yang menjadi suatu permasalahahan, dimana kalangan yang kontra menganggap bahwa hukuman kebiri adalah hukuman yang tidak manusiawi dan melanggar hak asasi manusia.

Dianggap berbenturan dengan hak asasi manusia, karena hukuman kebiri merupakan hukuman yang dapat menimbulkan berbagai efek samping yang dapat timbul pada tubuh pelaku kekerasan seksual. Efek samping yang dapat ditimbulkan dari hukuman kebiri inilah yang kemudian dianggap tidak manusiawi dan melanggar hak asasi manusia. Efek samping yang dapat timbul dari adanya kebiri kimia meliputi:

a. Meningkatkan kecemasan, stress, depresi dan frustasi;

b. Mudah lelah

c. Bulu badan berkurang;

d. Memperbesar kelenjar payudara pada pria;

${ }^{7}$ Dian Aryani Fajar dan Erwin Aditya Pratama, Perlindungan Terhadap Disabilitas Dalam Kebijakan Hukum Pidana (Sebagai Pelaku Maupun Korban), Justicia Sains Volume 3 (II), 2018, hlm 90 - 103. 
e. Mengurangi massa otot;

f. Meningkatkan berat badan, yang berakibat menaikkan resiko penyakit jantung dan pembuluh darah;

g. Mengurangi kerapatan tulang yang berakibat meningkatkan resiko osteoporosis;

h. Hipertensi;

i. Meningkatkan kadar gula darah;

j. Memperkecil ukuran testis;

k. Tak mampu ereksi;

1. Mengurangi jumlah sel sperma ${ }^{8}$.

Efek samping itu menjadi salah satu pertimbangan dimana hukuman kebiri tidak seharusnya diterapkan. Pelaksanaan hukuman kebiri kimia juga mendapatkan penolakan oleh Ikatan Dokter Indoesia (IDI), lantaran penyuntikan zat kimia terhadap pelaku kekerasan seksual bertentangan dengan kode etik dokter yang diatur dalam Surat Keputusan Pengurus Besar Ikatan Dokter Indonesia Nomor.221/[B/A.4/04/2002 Tentang Kode Etik Kedokteran Indoesia pasal 7 A yang berbunyi “ Seorang dokter harus, dalam setiap praktik medisnya, memberikan pelayanan medis yang kompeten dengan kebebasan teknis dan moral sepenuhnya, disertai rasa kasih sayang (compassion) dan penghormatan atas martabat manusia" dan pasal 7 D yang berbunyi " setiap dokter harus senantiasa mengingat akan kewajiban melindungi hidup makhluk insani"

Kejahatan kekerasan seksual terhadap anak telah disepakati bersama sebagai kejahatan yang biadab dan tidak dapat di maafkan. Masa depan anak menjadi korban lantaran akibat dari kekerasan seksual yang ia alami, memberikan rasa trauma dan malu untuk bergaul dengan orang lain. Indonesia merupakan negara yang masih menerapkan hukuman pidana mati, bukankah akan lebih pantas jika pelaku tindak kejahatan seksual terhadap anak seharusnya dihukum mati, sebagai balasan yang setimpal atas perbuatan yang dilakukan oleh pelaku kekerasan seksual. Hukuman kebiri kimia tidak serta merta dapat meminimalisir terjadinya kekerasan seksual terhadap anak.

Kekerasan terhadap anak justru dapat diminimalisir dengan melakukan upaya pencegahan lain yang seharusnya dirumuskan dengan

8 Ismantoro Dwi Yuwono,"Penerapan Hukum dalam Kasus Kekkerasan Seksual Terhadap Anak",Yogyakarta;Pustaka Yustisia,2015 
baik, hukuman kebiri bukanlah menjadi solusi yang tepat dalam kasus ini. Berdasarkan teori Plato tentang hukum sebagai sarana keadilan ia merumuskan sebagai berikut :

1. Hukum merupakan tatanan terbaik untuk menangani dunia fenomena yang penuh situasi ketidak adilan;

2. Aturan-aturan hukum harus dihimpun dalam satu kitab, supaya tidak mucul kekacauan hukum;

3. Setiap undang-undang harus didahului preambule tentang motif dan tujuan undang-undang tersebut; hal ini bermanfaat agar masyarakat dapat mengetahui dan memahami kegunaan menaati hukum itu, dan insaf tidak baik menaati hukum hanya karena takut dihukum;

4. Tugas hukum adalah membimbing para warga (melalui undangundang) pada suatu hidupp yang saleh dan sempurna;

5. Orang yang melanggar Undang-unang harus dihukum. Tapi hukuman bukanlah suatu balas dendan, sebab pelanggaran merupakan suatu penyakit intelektual manusia karena kebodohan. Seorang penjahat belum cukup tahu tentag keutamaan yang harus dituju dalam hidup, pengetahuan ini dapat ditambah lewat pendidikan sehingga sembuh dari penyakitnya. Cara mendidik itu adalah dengan lewat hukuman. Hukuman bertujuan untuk memperbaiki sikap dan moral si penjahat, namun apabaila penyakit terhadap sikap moralnya tidak dapat disembuhkan atau diperbaiki, maka penjahat tersebut haruslah dibunuh'.

Perilaku sex menyimpang yang dilakukan oleh orang dewasa terhadap anak ini merupakan perilaku yang sulit untuk diperbaiki atau disembuhkan, maka hukuman mati merupakan solusi yang tepat untuk para predator anak tersebut, agar tidak ada anak yang menjadi korban dalam kekerasan seksual.

Hukuman mati memanglah hukuman yang sama-sama berbenturan dengan hak asasi manusia yang melanggar pasal 28 huruf A Undang-Undang Dasar 1945 dan pasal 39 ayat (1) Undang-undang Nomor 39 tahun 1999 tentang Hak Asasi Manusia yang menyatakan bahwa setiap orang mempunyai hak untuk hidup, mempertahankan hidup dan meningkatkan taraf kehidupannya. Hukuman mati tidak memberikan rasa sakit atau penderitaan yang harus dialami pelaku setelah mendapatkan hukuman pidana mati, namun ukuman

${ }^{9}$ Bernard L. Tanya, dkk, "Teori Hukum Startegi Tertip Manusia Lintas Ruang dan Generasi", Yogyakarta; Genta Publishing, 2013 
kebiri memberikan penderitaan yang tidak manusiawi dimana ia harus menahan hasrat seksualnya, dengan hukuman kebiri menutup kemungkinan bagi si pelaku untuk meneruskan keturunan karena ia tidak bisa melakukan ereksi dan ini berbenturan dengan pasal 28 ayat (1) Undang-Undang Dasar 1945 dan pasal 10 Undang-Undang Nomor 39 tahun 1999 tentang Hak Asasi Manusia yang menyatakan bahwa setiap orang berhak membentuk suau keluarga dan melanjutkan keturunan melalui perkawinan yang sah. Hal itu menjadi suatu penyiksaan terhadap pelaku kekerasan seksual, sehingga hukuman mati akan jauh lebih pantas karena ia hanya mengalami rasa sakit saat ditembak mati. Pemerintah tidak perlu membiayai biaya penyuntikan zat kimia pada pelaku kekeran seksual terhadap anak, melainkan pemerintah dapat lebih memfokuskan pada penanganan terhadap anak yang menjadi korban kekerasan seksual.

\section{Pemberlakuan Eksekusi terhadap Hukuman Kebiri}

Suatu perundang-undangan dianggap sah dan berlaku serta mengikat kepada seluruh warga negara setelah diundangakan oleh pemerintah. Peraturan perundangn-undangan dibuat dengan disertai petunjuk pelaksanaan dan petunjuk teknisnya, namun dalam undang-undang nomor 17 tahun 2016 tentang Penetapan Peraturan Pemerintah Pengganti UndangUndang Nomor 17 tahun 2016 tentang Perubahan kedua atas Undangundang Nomor 23 tahun 2002 tentang Perlindungan Anak belum terdapat petunjuk pelaksanaannya. Masalah muncul ketika hukuman kebiri kimia dalam undang-undang tersebut diterapkan oleh hakim untuk memvonis pelaku kejahatan kekerasan seksual terhadap anak. Pelaksanaan eksekusi terkait dengan hukuman kebiri ini pun kemudian mengalami hambatan yang cukup sulit, dimana dokter melalui Ikatan Dokter Indonesia (IDI) menolak untuk melakukan penyuntikan dalam hukuman kebiri kimia. Penolakan yang dilakukan oleh IDI ini dilakukan lantaran penyuntikan tersebut bertentangan dengan kode etik dokter, undang-undang kesehatan .

Ketidak pastian terhadap pihak yang diberi wewenang sebagai eksekutor yang membantu jaksa dalam melaksanakan putusan kebiri kimi ini pun menjadi suatu hambatan bagi jaksa. Hukum mengenal asas nullum delictum noela poena sine preavia lege poenali atau yang sering disebut dengan asas legalitas, yang diatur dalam pasal 1 ayat (1) KUHP, dimana tidak ada suatu perbuatan dapat dipidana kecuali atas kekuatan aturan pidana dalam perundang-undangan yang telah ada sebelum perbuatan dilakukan. 
Kekuatan aturan pidana dalam undang-undang sebelum disahkan tentunya harus diperkuat dengan adanya pedoman petunjuk pelaksanaan dan teknis dalam pelaksanaan undang-undang tersebut. Petunjuk pelaksanaan dan teknis menjadi penguat akan undang-undang yang telah dibuat, sehingga dalam pelaksanaannya harus dijalankan berdasarkan aturan dan pedoman yang telah ada, sama halnya dengan ketentuan pelaksanaan hukuman pidana pokok yang diatur dalam pasal $10 \mathrm{KUHP}$, mengatur secara jelas terkait dengan pelaksanaan hukuman pokok tersebut.

Pelaksanaan hukuman kebiri menjadi salah satu pengingkaran terhadap tujuan hukum yang seharusnya memberi kepastian hukum. Berdasarkan pasal 81 huruf A Undang-undang Nomor 16 tahun 2017 tentang perubahan kedua atas Undang-undang Nomor 23 tahu 2002 tentang Perlindungan anak, hanya menjelaskan terkait sebagi berikut :

1) Pengenaan hukuman kebiri kimia dikenakan untuk jangka waktu paling lama 2 (dua) tahun dan dilaksanakan setelah terpidana menjalani pidana pokok.

2) Pelaksanaan tindakan hukuman kebiri kimia di bawah pengawasan secara berkala oleh kementerian yang menyelenggarakan urusan pemerintahan di bidang hukum, sosial, dan kesehatan.

3) Pelaksanaan kebiri kimia disertai dengan rehabilitasi.

4) Ketentuan lebih lanjut mengenai tata cara pelaksanaan tindakan dan rehabilitasi diatur dengan Peraturan Pemerintah.

Point ke empat menjadi kunci dalam pelaksanaan hukuman kebiri, dimana dalam pada point ke empat harusnya mengatur tentang bagaimana pelaksanaannya, siapa yng menjadi eksekutor dalam penyuntikan kebiri kimi dan waktu pelaksanaan secara detail dalam penyuntikan hukuman kebiri kimia, sehingga menimbulakn ketidak pastian hukum yang kini terjadi. Pemerintah melalui lembaga legislative harusnya segera menyusun terkait dengan pedoman pelaksanaan dan teknis dalam pelaksanaan hukuman kebiri sebelum jatuh pada waktu pelaksanaan hukuman kebiri itu sendiri.

Eksekusi hukuman kebiri akan relevan untuk dilaksanakan apabila telah ada pedoman petunjuk pelaksanaan dan teknis yang telah ada, sehingga asas legalitas tidak hanya diberlakukan hanya karena sudah ada undang-undang yang mengatur tentang kejahatan itu sendiri, melainkan juga berlaku pada pedoman pelaksanaan dan teknis dalam menjalankan undang-undang yang telah diundangkan, sehingga memberikan nilai kepastian hukum. 


\section{E. Simpulan}

1. Sejatinya semua hukuman bagi para pelaku kejahatan baik pelaku kekerasan seksual maupun pelaku kejahatan yang lainnya merupakan hukuman yang melanggar hak asasi manusia. Hukuman tidak serta merta suatu penderitaan yang dibebankan kepada pelaku kejahatan sebagai balasan atas perbuatnnya, melainkan dapat memberikan pelajaran dan keinshafan bagi pelaku agar tidak dapat melakukan kejahatannya kembali. Pemberian hukuman kebiri terhadap pelaku kekerasan seksual dalam kasus ini merupakan pemberian hukuman yang kurang tepat. Pemberian hukuman bagi pelaku kekerasan dalam kasus ini patutnya diberi hukuman mati, karena sejatinya perilaku menyimpang ini merupakan perilaku yang sulit untuk disembuhkan atau dihilangkan dari diri pelaku, meskipun telah dilakukan hukuman kebiri, keinginan untuk melakukan hal tersebut masihakan tetap ada, dan tidak menutup kemungkinan dapat melakukan hal tersebut dikemudian hari.

2. Asas legalitas menjadi salah satu asas yang selalu digaungkan dalam dunia hukum, lantas apakah asas ini hanya berlaku pada suatu undang-undang yang menyatakan suatu kejahatan, pelanggaran dan hukumannya. Kepastin hukum menjadi salah satu tujuan dari hukum, namun jika suatu hukuman dapat diberikan tanpa adanya petunjuk pelaksanaannya, maka hukuman akan dapat dilaksanakan dengan cara apapun selagi hukuman itu dapat sesuai dengan hasil putusan hakim. Pelaksanaan hukuam kebiri dalam kasus ini akan dilakukan pada saat 2 tahun sebelum selesai menjalani hukuman pokok, dalam hal ini DPR harus segera menyusun pedoman pelaksanaan dan teknis terkait dengan hukuman kebiri.

\section{Daftar Pustaka}

\section{Buku}

Dwi Ismantoro Yuwono, Penerapan Hukum dalam Kasus Kekerasan Seksual Terhadap Anak, Yogyakarta: Pustaka Yustisia, 2015.

Efendi Jonaedi, Jhonny Ibrahim, Metode Penelitian Hukum Normatif fan Empiris, Depok : Prendamedia Grup, 2018.

Marzuki Peter Mahmud, "Penelitian Hukum Edisi Revisi" , Jakarta: Prenadamedia Group, 2016. 
Moeljatno,"Kitab Undang-Undang Hukum Pidana", Jakarta, PT. Bumi Aksara, 2016.

Qamar Nurul, dkk, "Metode Penelitian Hukum (Legal Research Methods)", Makassar: Cv.

Social Politic Genius (SIGn), 2017.

Sugiyono, " Metode Penelitiaan Hukum Kuantitatif, Kualitatif, dan RED", Bandung:

Alvabeta Cv, 2017.

\section{Jurnal}

Aryani Fajar Dian dan Erwin Aditya Pratama, Perlindungan Terhadap Disabilitas

Dalam Kebijakan Hukum Pidana (Sebagai Pelaku Maupun Korban), Justicia Sains Volume 3 (II), 2018.

Sudewo Fajar Ari, dkk, The Application Of Restorative Justice System Through The

Diversion Of Children In Conflict With Laws In Central Java Polda (Regional

Police Of The Republic Of Indonesia), International Journal of Psychosocial

Rehabilitation Volume 24 (2), 2020.

\section{Website}

liputan6, “ PN Mojokerto: Hukuman Kebiri Kimia Terhadap Pemerkosa Anak

Berpatok Undang-undang", https;//m.liputan6.com/Surabaya/read/4047883/pn-

mojokerto-hukuman-kebiri-kimia-terhadap-pemerkosa-anak-berpatok-uu-,

Kamis ,Tanggal 29, Agustus tahun 2019

Ni'mah Faricha, 2015 , Analisis Data dalam Penelitian Kualitatif, diakses dari

https:/www.google.com/amp/s/www.kompasiana.com/amp/farichatun/analisis-

data-dalam-penelitian-kualitatif_556b6d1f2ab0bd174de40eed, Selasa, 24

Desember, 2019, 22:24

\section{Peraturan Perundang - Undangan}

Undang-Undang Dasar Negara Republik Indonesia Tahun 1945

Undang-Undang Nomor 39 Tahun 1999 Tentang Hak Asasi Manusia

Undang-Undang Nomor 17 Tahun 2016 Tentang Penetapan Peraturan Pemerintah

Pengganti Undang-Undang Nomor 1 Tahun 2016 Tentang Perubahan Kedua Atas

Undang-Undang Nomor 23 Tahun 2002 tentang Perlindungan Anak. 
Peraturan Pemerintah Pengganti Undang-undang Nomor 1 tahun 2016 tentang Perubahan Kedua Atas Undang-Undang Nomor 23 Tahun 2012

Surat Keputusan Pengurus Besar Ikatan Dokter Indonesia Nomor.221/[B/A.4/04/2002

Tentang Kode Etik Kedokteran Indoesia 